\title{
The Role Of Cross-Cultural Understanding in Interpreting English Recount Texts
}

\author{
Roni Sa'roni, ronyline10@gmail.com, UIN SyarifHidayatullah Jakarta, Jakarta, Indonesia \\ Didin NuruddinHidayat,didin.nuruddin@uinjkt.ac.id, UIN SyarifHidayatullah Jakarta, \\ Jakarta, Indonesia
}

\begin{abstract}
This study aimed at analyzing the role of cross-cultural understanding in interpreting English recount texts. The data of this study were obtained by reviewing documents of a book entitled "Histories of Nations: How Their Identities Were Forged" (Furtado, 2017). As a qualitative content analysis, all the data were analyzed qualitatively by classifying, coding, and interpreting the data. The study found that there were some words and phrases in the recount text that requires cross-cultural understanding to interpret those texts accurately. Therefore, in interpreting the recount text, it is necessary to understand not only the text in the literal meaning but also the cultural context in a comprehensive way. It focuses on cultural context deals with the history of social organization and religion systems. Cross-cultural understanding eases the readers to interpret the recount text appropriately. The study suggests that cross-cultural understanding should be an essential topic to be learned intensively in learning the English language at least at university education level as it will enable students to be capable of understanding English discourses comprehensively.
\end{abstract}

Keywords: Cross-cultural understanding, Interpretation, Recount text, Content analysis

\section{INTRODUCTION}

As pointed out by Furtado (2017), if we fail to understand how others think and feel about their past, we will fail to understand them. In the writer's opinion, it means that the learning history of other nations is significant in today's context, considering the earth we live as a global village. Furthermore, the widespread of the internet accessibility, causing people all over the world are easily connected. In learning a language by using the Genre-Based Approach (GBA), understanding history can gain through recount text. As an explanation, this text is a type of text which talks about events or experiences within the past in temporal sequence based on the writer's experiences (Noviyanti, 2015; Tuan, 2011).

Due to understand an English recount text comprehensively, we have to understand the cultural context where that language exists. Notably, there is no debate that language is always influenced and shaped by culture. In other words, it reflects the culture and vice versa. Therefore, understanding a language also should involve guessing a culture. In this context, the writer argues that cross-cultural understanding has a significant position in terms of interpreting English recount text. Cross-cultural understanding is concerned with understanding people from different cultural backgrounds and how people interpret their understanding (Pujiyanti \& Zuliani, 2014; Ricoeur, 1976). In other words, the quality of interpreting or understanding English recount text depends on the comprehension of cultural context related to that text. For instance, an English recount text that tells historical events not

124 | IJET| Volume. 9, Issue 1. July 2020 Copyright 2020 Roni Sa'roni \& Didin NuruddinHidayat are licensed under Creative Commons AtrributionShareAlike 4.0 International License. 
only deals with the text itself but also with the cultural context. At this point, it can be in the form of politics, economy, social, and so on-those interconnected at the time when certain historical events occurred.

Concerning the recount text, Noviyanti (2015)explains that it usually covers an obligatory orientation. It deals with providing information related to the participants' situation. Afterward, a record of events is presented later, which tells the listener or reader about what the participants have undergone. In the end, the reorientation phase is optional. In other words, it can be presented explicitly or not. It usually leads the listener or reader back into the present. Besides, she elaborates the language features of recount text as a) It identifies the specific participants, for instance: I, my big family; b) It is written in the form of simple past tense; c) It uses verbs action such as celebrated, went, got, and said; d) It takes conjunctions or connectives, for instance:soon after, then, and when; e) The first speaker employed, for example:I, We; f) It explains the events those focus on constructing a readable text; g) It sometimes is covered personal impression, exclude factual recount; h) It utilizes descriptive words to offer detail explanation that deals with who, what, and how; and i)It employs proper noun aimed at recognizing the characters involved.

In the present study, the researchers focus on conducting a content analysis of recount text in the book entitled "Histories of Nations: How their identities were forged" from page 166 to 189(Furtado, 2017). This book was selected based on the researchers' preference due to their interests in historical events related to three countries: theUnited Kingdom (UK), the United States of America (USA), and Australia. Newmark (1981)describes culture as a way of life of a particular society that is expressed by specific languages. Meanwhile, Clifford Geertz states that culture defined as a symbolic meaning system. Thus, culture can also perceive as all forms of thought, tradition, ability, art, and device or equipment which characterize the community of people or society within a specified period. In detail, universal culture can divide into seven categories: language, knowledge system, social organizations, life tool system, livelihood system, religion system, and art(Pujiyanti \& Zuliani, 2014).

In Indonesian culture, the background of speakers or addressees influences the language they use(Fitriah \& Hidayat, 2018). It can be in the form of family relationships, social relationships, age, gender, and status. It appears at how Sundanese or Javanese people use language in their daily conversation to make it clear. The language they use reflects cultural values such as politeness manner. The main point the writer highlights is that language and culture are interconnected one each other. Meanwhile, Marlisa and Hidayat (2020) emphasize that building delivered information successfully during the process of interaction is not easy; the speaker and listener will face some mistakes or misunderstandings.

The majority of cross-cultural misunderstanding takes place when the meaning of words/phrases within two languages is considering identical, but those should interpret culturally different. For that reason, the researchers focus on analyzing the role of cross-cultural understanding to interpret English recount text. The differences in culture in the UK, USA, and Australia cause an impact on the different interpretations of the same words. Cultural context refers to the culture, tradition, and circumstance of a language societies where the speakers involve as an integral part of that system. Later on, Song (2010)underlines that language is a social phenomenon that makes it inseparable from the social structure as well as an integral part of the value system established within society.

As a consequence, language is impossible to separate from being affected by all social aspects such as status, role, gender, age, and so on. Thus, understanding the English recount text requires not only lexical meaning literally but also contextual interpretation culturally. In brief, language and culture have a close relationship, which is causing influence on each other.

125 | IJET | Volume. 9, Issue 1. July 2020 Copyright 2020 Roni Sa'roni \& Didin NuruddinHidayat are licensed under Creative Commons AtrributionShareAlike 4.0 International License. 
Referring to the explanation in previous paragraphs, the researchers formulated the research question as follows: to what extent does the role of cross-cultural understanding to interpret English recount text in the book entitled "Histories of Nations: How their identities were forged"?Based on that research question formulated earlier, the objective of the research is to know the role of cross-cultural understanding in interpreting English recount texts in the book entitled "Histories of Nations: How Their Identities Were Forged."

\section{METHOD}

The research design of this study was based on the paradigm of qualitative content analysis. Regarding this research design, Qualitative content analysis can understand as a research method aimed at in-depth investigation about personal interpretation in terms of research data obtained in the form of written text by employing several processes of systematic classification through coding and identifying themes or patterns(Mayring, 2014). Afterward, it should present the form of verbal descriptions; in short, Content analysis designed to analyze the written text documents.

The procedure of data collection for this study achieved using a document review of the book entitled "Histories of Nations: How their identities were forged."Accordingly, there were three chapters analyzed. Firstly, Great Britain: The confected nation-state, written by Jeremy Black. Secondly, The United States: The land that chose to be without history, written by Peter Unof. Moreover, lastly, Australia: A European nation in an ancient land, written by Stuart Macintyre.

Regarding the procedure of data analysis, this study combined seven steps from different authors (Miles et al., 2014; Sitoresmi, 2017). They are:1) Perusing, in doing textbook analysis, the researchers perused the cultural material carefully. It can be page by page and line by line. All pages and lines that contain cultural material were marked. 2) Marking or checklist, marking, or list used to help to code the cultural content. 3) Classifying the cultural content can be classified into the most frequent event, the less frequent one and finally the least frequent one. It was reviewed based on the theoretical foundation presented before. Then, it compared to the relevant studies discussed previously. 4) Coding, it was employed in analyzing data-the research data organized in terms of basic things-utilizing coding. Notably, coding is more than merely assembling the data. It also helps the researchers to systematize the process of analyzing data. The researchers used several codes to categorize the cultural contents of this study easily. 5) Tabulating, after marking and commenting on the entire content of the text, the researchers organized the research data of written text in the form or worksheet provided. Each of them compiled into each chapter, and then it can be arranged entirely. 6) Interpretation in this phase, the researchers interpreted the data gathered based on theoretical foundations relevant to the role of cross-cultural understanding in understanding English recount text, as has been discussed in the previous section. 7) Trustworthiness, to ensure the validity and reliability of the data gathered in this study, triangulation was employed. Triangulation intended to check the credibility of the inferences resulted from the research findings.

\section{RESULT}

In the beginning, the researchers perused the content of the book entitled "Histories of Nations: How Their Identities Were Forged"word by word, phrase by phrase, and sentence by sentence. It intended to identify whether each of them can be interpreted only by understanding the culture as a context beyond the text itself or not. Accordingly, it is necessary to have an ability to understand the English recount text not only based on lexical meaning literally but also based on the cultural context where the language used as a means of communication in a

126 | IJET $\mid$ Volume. 9, Issue 1. July 2020 Copyright 2020 Roni Sa'roni \& Didin NuruddinHidayat are licensed under Creative Commons AtrributionShareAlike 4.0 International License. 
society. Hence, there are no difficulties faced by the reader in understanding or interpreting the meaning of the text comprehensively.

Discussing the role of cross-cultural understanding to interpret English recount text, the writer analyzed it in line with the theory of universal culture (Pujiyanti \& Zuliani, 2014). At this point, there are seven categories of global culture. In the table presented below, data analysis is narrowed based on the category of social organization and religion system. Due to the content of the recount text dealing with history, there are some words and phrases usually found in historical events that can be interpreted easily by understanding the context beyond those words and phrases.

Talking about the content of the book, the writer divided it into three sections. Section 1 deals with the text entitled "Great Britain: The Confected NationState," written by Jeremy Black (pages 166-173). Next, section 2 deals with the text entitled "The United States: The Land That Chose to Be Without History, "written by Peter Unof (pages 174-182). Further, section 3 deals with the text entitled "Australia: A European Nation in an Ancient Land," written by Stuart Macintyre (pages 183-189).

The table below presents words and phrases to be analyzed and discussed further. It is in line with the context of interpretation as has been explained in previous relevant theoretical foundation:

Table 1 The Tabulation of Words and Phrases in English Recount Text following the Chosen Topic

\begin{tabular}{|c|c|c|c|c|}
\hline \multirow{2}{*}{ No } & \multirow{2}{*}{ Topic } & \multicolumn{3}{|c|}{ Words and Phrases in English Recount Text } \\
\hline & & Section 1 & Section 2 & Section 3 \\
\hline 1 & $\begin{array}{l}\text { Social } \\
\text { organizations }\end{array}$ & $\begin{array}{l}\text { Monarchy, county, } \\
\text { dominion, } \\
\text { overseas, }\end{array}$ & $\begin{array}{l}\text { Federal state, county, } \\
\text { electoral college, } \\
\text { governor, speaker of } \\
\text { the house, federal } \\
\text { reserve, US secretary }\end{array}$ & $\begin{array}{l}\text { Commonwealth, } \\
\text { colonies, Governor- } \\
\text { General, upper house }\end{array}$ \\
\hline 2 & Religion system & $\begin{array}{l}\text { Anglicanism, } \\
\text { Church }\end{array}$ & $\begin{array}{l}\text { Church, pilgrims, } \\
\text { evangelicalism, } \\
\text { Mormonism }\end{array}$ & Church \\
\hline
\end{tabular}

Language is using as a means of communication in a particular society. Meanwhile, the culture lies in that society influences how that language used and interpreted. In the category of social organization, the writer elaborated on some words and phrases cited in the book entitled "Histories of Nations: How Their Identities Were Forged." The term "monarchy" is popularly known in Great Britain due to this nation as the United Kingdom (UK). Whereas in the United States of America (USA), as a federal republic, it is in the opposite. The US President is not elected by direct vote when the presidential election carried out but by a complicated electoral College system. On the contrary, in England, the phrase "electoral college" is not a familiar vocabulary.

Different from the UK and US, for Indonesian people in general, it is difficult to understand the word "county" as a government level. Cited from Cuomo and Rosado (2018), the county is a municipality level following territorial jurisdiction, autonomy rules, and the fiscal powers to provide several services to its citizens. In contrast, in our country, the level of

127 | IJET| Volume. 9, Issue 1. July 2020 Copyright 2020 Roni Sa'roni \& Didin NuruddinHidayat are licensed under Creative Commons AtrributionShareAlike 4.0 International License. 
local government consists of "Province (Provinsi)" and "Regency or City (Kabupatenor Kota)" as an integral part of the unitary state.

As a result of colonization, Great Britain has "dominion overseas. "Besides, Australia is well known as "Commonwealth Nations." Without understanding the history of colonization, this word is unfamiliar, particularly in the country which was never occupied by Great Britain in the imperialism era, such as Indonesia.

In Indonesia, "Governor" is commonly known as the head of the local government of the province. In the US, "Governor" is chief executive of state government while President is that of federal-state government located in Washington DC. Meanwhile, in Australia, there are "Governor-General" at the federal level and then "Governor" at state one. The differences in the political system and political culture determine the context of how the technical terms in a specific language are interpreted and understood. It can be in the form of both words and phrases.

The legislative body, following the bicameral system, consists of "upper house" and "lower house" (Drexhage, 2015). For Indonesian people, understanding the interpretation of those terms requires cross-cultural understanding about how that political system culturally implemented in those countries. On the other hand, the use of the phrase "speaker of the house"rather than "head of the house" or "head of Parliament" is due to the context of the language used in that system.

In the Indonesian government, there are "Minister of Foreign Affairs" and "Minister of State Secretary" as members of a cabinet appointed by the President. In contrast, in the US, the mean of "State Secretary" is "Menteri Luar Negeri. "Also, "Menteri Pertahanan" is not called "Minister of Defense" like in Indonesia, but as "Secretary of Defense." In the US, "the Federal Reserve" or shortly called "the Fed" has the same contextual meaning as "Bank of Indonesia" or BI in Indonesia. The two are functioning as "Central Bank. "Those differences have resulted in the cultural context in the economic system implemented in each of the countries.

Regarding the culture category religion system, as well as the previous discussion, it can also elaborate in the following:

a. As discussed in Furtado (2017), "Anglicanism" refers to the school of thought of the Christian community in western tradition concerning performance, liturgy, and adherents' identity of the England Church as a result of Protestant Reformation. Assuming religion as a part of universal culture, we will have no comprehensive understanding and even misinterpretation about what Anglicanism is if only based on lexical meaning literally by ignoring its context at all;

b. As explained by Itulua-Abumere (2013), "Church" is a building used for Christian religious activities, particularly for worship services. Whereas looking at the context where the word "Church" used in the western world. This term also used for buildings of ritual activities of other religions; in the US, Muslims perform their worship at church. It means that the church in this context can be interpreted as the same as "Masjid" or "Mosque" in the Indonesian context. On the contrary, the word "Church" or "Gereja" defined as a previous understanding by almost Indonesian people. Therefore, the same word used in different context producing different both meaning and interpretation;

c. In general, "pilgrimage" can be defined as a physical journey to a specific holy city performed by specific religion adherent to fulfill spiritual or religious commands as regulated in the religious belief system. In particular, Islamic teachings define this term by narrowing this concept is in line with the fifth of five pillars of Islam (performing hajj), so do the understanding of "prayer" as "sholat" fasting" as "shaum," ablution" as "wudhu," and the others;

128 | IJET | Volume. 9, Issue 1. July 2020 Copyright 2020 Roni Sa'roni \& Didin NuruddinHidayat are licensed under Creative Commons AtrributionShareAlike 4.0 International License. 
d. As highlighted by Mouw and Millet (2012), "Evangelicals" is the single largest religious group in the US. In Great Britain, there are "Anglican Evangelicals. "The look at the context of the language used pragmatically. There are always many ways of interpreting the same words. The other example is "Mormonism." It associates with the community of the Church of Jesus Christ of Latter-day Saints (LDS Church) because of the Book of Mormon they believe in, although its community is frequently referring themselves as Latter-day Saints or sometimes just Saints.

\section{CONCLUSION}

The study concludes that to interpret the English recount text appropriately, we have to understand the relevant context comprehensively, focusing on the cultural context. As Indonesian people, to understand words, phrases, and sentences regarding the history of Great Britain, the United States of America, and Australia, we require to understand the context relevant to the topic discussed. To sum up, there is no debate that cross-cultural understanding has a significant role in interpreting an English recount text.

Following the research findings, the researchers suggest that cross-cultural understanding should be an essential topic to be learned intensively in learning the English language at least at the university education level. It will enable students to be capable of understanding English discourses comprehensively. Afterward, it also allows students to be culturally literate. Hence, learning a language can contribute to building multiculturalism in our society and our country, Indonesia. As a result, the word will strengthen ethical culture and vice versa. 


\section{REFERENCES}

Cuomo, A. M., \& Rosado, R. (2018). Local Government Handbook. San Francisco State University: Pearson Education, Inc.

Drexhage, B. (2015). Bicameral legislatures: An international comparison. Ministry of the Interior and Kingdom Relations.

Fitriah, F., \& Hidayat, D. N. (2018). Politeness: Cultural Dimensions of Linguistic Choice. Indonesian Journal of English Education, 5(1), 26-34.

Furtado, P. (2017). Histories of Nations: How their identities were forged. Thames and Hudson Ltd.

Itulua-Abumere, F. (2013). The church: Yesterday and today. Flourish Itulua-Abumere.

Marlisa, R., \& Hidayat, D. N. (2020). The analysis of Flouting Maxim in Good Morning America (GMA) talk show. English: Journal of Language, Education and Humanities, $7(2), 137-149$.

Mayring, P. (2014). Qualitative content analysis: Theoretical foundation, basic procedures, and software solution. Leibniz Institute.

Miles, M. B., Huberman, A. M., \& Saldana, J. (2014). Qualitative data analysis: A method sourcebook. SAGE Publication.

Mouw, R. J., \& Millet, R. (2012). Evangelicals \& Mormons: A conversation \& dialogue. Brigham Young University.

Newmark, P. (1981). Approaches to translation. New York: Pergamon Press.

Noviyanti, N. (2015). Thematic progression in students' recount texts. Journal of English and Education, 3(2), 65-76.

Pujiyanti, U., \& Zuliani, F. R. (2014). Cross-cultural understanding: A handbook to understand others' cultures. CV. Hidayah.

Ricoeur, P. (1976). Interpretation Theory: Discourse and the surplus of meaning. The Texas Christian University Press.

Sitoresmi, W. E. (2017). A cultural content analysis of EFL textbooks - Challenge Series: 2, 3, and 4 Published by Pearson. UIN Syarif Hidayatullah Jakarta.

Song, L. (2010). The role of context in Discourse Analysis. Journal of Language Teaching and Research, 1(16), 876-879.

Tuan, L. T. (2011). Teaching writing through Genre-Based Approach. Theory and Practice in Language Studies, 1(11), 1471-1478. 